\title{
IMPROVING DESCRIPTIVE WRITING ABILITY OF THE FIRST YEAR STUDENTS OF SMA TOHA PRAKTIKA GILIGENTING-SUMENEP BY USING PICTURES
}

\author{
Rini Yudiati \\ Prodi Pendidikan IPA, Universitas Wiraraja Sumenep
}

\begin{abstract}
In Indonesia English is a foreign language, not a second language. As a result, it is very difficult for the students to write a paragraph in English because writing is a complex process that allow writers to explore thoughts and ideas, and make them visible and concrete. The indonesian students' achievement in writing descriptive paragraph is very low due to several reasons. Firstly, the Indonesian community does not support the existence of the English situation

Based on the fact, the researcher focuses this thesis on the problem of improving descriptive writing ability of the first year students of SMA Toha Praktika Giligenting Sumenep by using pictures. The research problem is How can the use of pictures improve the students'ability in writing a descriptive paragraph at SMA Toha Praktika?. The researcher thought that if the students can develop their imagination by the pictures, they will be able to create descriptive paragraphs that are meaningful.

To answer the research problem, this research use the classroom action research at SMA Toha Praktika on the first year students academic year 2010/2011 who have difficulties in writing descriptive paragraph. Exercises was done to know how high the students' ability in writing descriptive paragraph. the data collection involved instruments, namely writing observation, composition test and questionnaires. The composition test was to measure the students' ability in writing descriptive and questionnaires was to know the students' opinion about the implementation of pictures. All of the data were analyzed and compared with the criteria of success that the minimun score of the students was 60 and there was $60 \%$ or 17 students mastered the material and can made descriptive paragraph.
\end{abstract}

Key Word: Picture, Improvement, Descriptive Writing.

\section{INTRODUCTION}

Language is the most important tool in social communication among people in any society. Without language, it is impossible for people to communicate with other people and do the activities succesfully.

One of the languages is English. Having a good English in all aspects of life becomes an expectation for many people in the world. An ability to communicate in English can help people think, write, speak don't do better things for developing their potencies in social life and social community. We can communicate with other people through speaking or writing. By writing we can evaluate the adequacy of a description and stimulate it to extend a line of thought beyond the first impressions or good responses. Besides it can help us understand how truth is established in a given discipline and give opinions without getting confused and confusing the reader.

As a means of communication, writing is used by people to inform their ideas or feeling to others. Therefore, as a means of teaching learning, through writing, people can gather or obtain information, to see connections between ideas, to organize ideas into an explainable concept, to void confusion, to absorb and process information, to learn actively (Hairston, 1986).

There are many reasons and ways to make the students write, but overall goals can be grouped into two categories which can help students understand and retain course information. The first is writing to demonstrate knowledge based on their necessary information. And the second is writing to improve or maintain writing skill in which style and correctness are important (Depdiknas, 2003:4). In order to facilitate their 
students to communicate in good writing, the teacher have tried many efforts with the suitable media for teaching writing in the class. Besides, there have been a number of techniques or methods to make the students able to write well.

However, the Indonesian students' achievement in writing descriptive paragraph is very low due to several reasons. Firstly, the Indonesian community does not support the existence of the English situation. Therefore, the students are hardly ever to practice writing because of the social cultural situation. Secondly, the differences of the English grammar construction as a target language and the students' native language (Indonesian) are low because English as second language in Indonesia . The pattern and rules in English is more complex than Indonesian and some words are more difficult to learn than other language.

The result of the preliminary study of students of SMA Toha Praktika Giligenting showed that the writing achievment of the first year students of SMA Toha Praktika is relatively low. The students' response from the interview indicated that writing occupies the second difficult subject of the four basic language skills. Listening is the second to be most difficult english skill among others followed by writing. They said that they are not in the habit of expressing their ideas in the written form, and it is hard for them to express their ideas, thought, feeling or even emotion because culturally they are not supposed to do.

The researcher as one of English teacher in SMA Toha Praktika Giligenting found the students' writing score is relatively low. It means that most of the students find difficulties in writing composition. The writing compositions are lack of organization of the content, diction or choice of appropriate words for particular context or setting, and the employment of grammatical and syntactical patterns. The total numbers of words quantitatively is less than the expected minimum mastery. They also say that writing lesson is boring lesson. Classroom assignments which are assumed to be handed out often un completed and are given as homework. Yet the result is still loose sentence lack of unity and coherence.

One of the methods of writing that was interesting is pictures. Pictures can increase the students senses and to make them imagine what they see, write them and analyze them in the thought. The researcher thought that if the students can develop and improve their descriptive writing by the pictures that can help them motivate in creating a descriptive paragraph. Teaching learning that used pictures is effective to tell the difficult concept of words. Through pictures, the students can make the rules of understanding, process, result, etc. (Suyatna, 2005: 12). The teacher gives the student something different in teaching learning and combination of pictures to improve the students' ability in writing descriptive paragraph.

Based on the facts, the use of pictures implemented increasing the students' ability in writing descriptive quality among students at SMA Toha Praktika Giligenting is an alternative way to solve the problem. It is a program which the students of SMA Toha Praktika Giligenting trained to make descriptive paragraph both of process and product. Writing is a process, not merely a product. The quality of the studets' writing will reflect the time and forethought the students put into the assignment. Plan ahead for the assignment by doing prewriting: this will allow the students to be more productive and organized when the students sit down to write. Also, schedule several blocks of time to devote to their writing; then, the students can walk away from it for a while and come back later to make changes and revisions with fresh mind. 


\section{PROBLEM OF THE STUDY}

Based on the background of the study above, the problems of the study is "How can the use of pictures improve the students' ability in writing a descriptive paragraph at the first year of SMA Toha Praktika Giligenting by using pictures?

The objective of the study is using pictures improved students' writing ability in writing a descriptive paragraph in the first year of SMA Toha Praktika Giligenting by using pictures.

The classroom action research used in English instruction (Latief, 2003) is an approach to English teacher's professional development and to improve students' learning in which English teacher's systematically collect data and reflect on their works and make changes in their English classroom practices. This study involved looking at student's learning difficulties, and classroom learning environment for the purpose of planning, implementing, observing, and reflecting the action. The result of the reflection gave feedback for the improvement of the plan in the previous cycle. And the final product of the action research for writing was a newly developed instructional strategy for presenting writing material. Kemmis \&Mc Taggart's involving three cycles of each of which there are four stages of planning, implementation, observation, and reflection and drawing conclusion was applied.

\section{FINDING AND DISCUSSION}

This chapter discusses the pictures strategy implemented to improve the ability of the students in writing a descriptive paragraph. the discussions are presented in line eith findings of the research. In this section, the researcher discusses the findings and related theories in order to interpret the findings of the present study.
A. Discussion on the Implementation Pictures to Improve the Students' Ability in Writing Descriptive Paragraph

To implement pictures in the teaching of writing, the researcher designed the lesson plan, conducted writing activity, and provided descriptive paragraph.

\section{Designing the Lesson Plan}

In designing the lesson plan the researcher formulated of objective because it was the important preparation before conducting a teaching activity. This activity directed the researcher to achieve the expected result from the lesson plan. On the other hand, for the students, formulating of objectives informed them what they would achieve during the process of teaching and learning. Kauchak and Eggen(1996) state that clear objectives are critical because the provide the framework for teacher's thinking as the guide their student's construction of the topics they are teaching. This means that our objectives are explicity stated. Hence, researcher could identify on what he wanted to be able to write. In addition, the specific instructional objectives formulated to improve the students' ability in writing a descriptive paragraph.

After formulating the objectives, the researcher and collaborative teacher designed a lesson plan. The researcher and collaborative teacher decided the curriculum content that is important for students to learn and how it can be enacted in classroom settings. According to Arends (2004:97) good planning involves allocating the use of time, choosing appropriate method of instrument, creating students'; interest, and building a productive learning environment.

The lesson plan was designed by adapting the competency based curriculum (CBC, 2004: 21). The researcher selected the materials which 
were appropriate with the aim of the study, which is improving the ability of the students in writing a descriptive paragraph through pictures.

\section{Conducting Writing Activity}

Conducting writing activities is the teacher's main task in teaching of writing. In this class, the teacher can use various ways in presenting the material in the classroom. The results of the research indicated the ways of presenting the materials could be grouped into three main activities; (1) pre writing activity, (2) whilst writing activity, (3) post writing activity.

\section{2. a Pre Writing Activity}

In the term of pre writing activity, there were subcategorized into the following activities, (i) greeting students in English, (ii) checking the attendance list, (iii) activiting the students' schemata, and (iv) word mapping.

The researcher opened the class by greeting the students in English to encourage and familiarize the students with English. It was expected that the students could practice using english with their friends,at least at school environment.

Another activity was checking the attendance list. In the present study, the researcher took the attendace list was one of the first administration task during the class period. At the first meeting in cycle 1 , the researcher checked the students' attendance by calling the students' name one by one. To be more efficient, for the later meeting, the teacher scanned the students or asked them who were absent to the captain of the class directly. This wy really worked well and allowed the researcher to proceed to the next activity.

Activating the students' schemata or facilitated the students with prior knowledge that migth help them understand the material easily. It was done by showing them pictures related to the topics, raising some questions, and asking some words related to describing somethings. Such activity could help the students to focus their attention understanding the materials.

Next activity conducted in pre writing activity was word mapping. It was done by asking the students to fing as possible vocabulary items related to the topic. Burn et al. (1996) indicate that the students should bu taught word recognition skill that will allow unlocking the meaning of unfamiliar words. This principle of teaching writing implies that teaching writing is not only laid down to writing good sentences or paragraph but it also suggest the teacher to integrate the teaching of writing to the teaching vocabulary discussion. Therefore, the researcher applied this principle of the teaching writing in her instruction.

\section{2. b Whilst Writing Activity}

There were several activities the researcher did in the whilst writing activity, namely, (1) Identify pictures gave by the teacher. It was done by asking the students to write a topic sentence and supporting ideas, (2) asking the students to develop a paragraph based on the focused question, (3) giving a help if necessary.

After the student gathering their ideas, the first attempt at writing. In this section, the researcher focused on students' fluency of writing. After that, the students soon were asked to develop a complete paragraph based on their draft. And, the students were suggested to develop their ideas as complete as possible and write neatly.

As the student worked individually, the researcher monitored their work to ensure that they could follow the instruction. Then, the researcher, together with the collaborative teacher, conducted student-teacher discussing to give feedback on what the students had done. 


\section{2. c Post Writing Activity}

Post writing activity was intended to encourage the students to reexamine their writing ability. To achieve this purpose, the researcher gave some activites such as rewriting paragraph and developing a paragraph based on the final draft.

\section{The Implementation of the Students' Ability in Writing Descriptive Paragraph}

The finding of the research showed that one of the strengths of picture series was that it could improve the students' ability in writing descriptive paragraph. This could be studied from the result of the analysis of process and product implemented throughout the research. The writing test was administrated by the researcher at the end of each cycle. The materials were taken from the topics selected by the students previously.

Having been trated with pictures, the students really made progress on their writing ability. This could be inferred from the result of the implementation of picture throughout the cycle (see appendix 8)

Such significant improvement was gained after the strategy was implemented and proved in three cycles containing seven meetings.

\section{B. The Using Pictures}

The teacher can used the pictures as an alternative to improve the teaching writing because the picture itself can make the students more interesting than using words or listening, bucause what the students see will be memorized longer than the students hear. The using pictures in teaching writing is more interesting and it can give motivation to the students to understand about materials longer and automatically. The picture can give meaning practically about the vocabulary and the grammar gave by the teacher. The teacher should use the picture series as media because the pictures are cheaper and easy to get and use. And to improve the motivation and memorizing and imagination of the students.

\section{CONCLUSION AND SUGGESTION \\ a. Conclusion}

The conclusion of this study deals with; (a) the appropriate teaching writing by using picture series that improves the students' ability in writing descriptive paragraph, and (b) the strength and weaknesses of the strategy applied.

\section{The Implementation of Pictures}

In order to be able to teach writing ability the researcher followed two kinds of procedure-the general and specific procedures. The general procedures required the researcher to follow particular steps. The first was designing the lesson plan which covered al activities needed in teaching and learning process. The next step was conducting writing activity which covered: (1) Pre-writing activity, (2) Whilst writing activity, (3) Post writing activity. The next step was providing pictures.

To teach writing using pictures, the researcher initialized her teaching focusing questions to activate the students' ability to lead them to the topic they were familiar with. Then, the researcher together with the collaborative teachers and the students selected topics and such activity was followed by pictures to find as many vocabulary items as possible. The process of writing was started when the students asked to write a topic sentence and some supporting ideas. After that, the students were asked to develop a paragraph based on the topic. The researcher then used pictures to help the students how to imagine writing descriptive paragraph.

Finally, before ending the class, the researcher and the collaborative teacher summarized and gave feedback on the previous discussion. Before leaving the class, the researcher asked the students 
to rewrite the paragraph at home and their feelings about what they had done that day. The teacher also asked the students to answer the questionnaries.

\section{The Strength and the Weaknesses of the Pictures}

The strength of pictures in teaching writing could be seen from the fact that this media could improve not only the students' ability in writing descriptive paragraph but also the students' motivation to study writing. The students guided to write a paragraph correctly through pictures.

In spite of the strengths discussed previously, it was found out that there were some weaknesses such as it required extra time especially during the evaluation and correction each other's work's stage. Beside, the students were expected to always be ready, participate fully, and write the paragraph correctly many times. Another problem appeared in the implementation such as strategy was the validity and reliability done by the students. However, such problem could be reduced by improving the clear criteria. The teacher was required to create a conductive atmosphere in the classroom.

\section{b. Suggestion}

Based on the findings of the research, the researcher addressed some suggestion to:

1. The teacher

Realizing that the pictures could improve the students' ability in writing descriptive paragraph. it is recommended for the teacher to apply this media as one of many alternatives used in teaching writing by following the particular steps: (1) Designing lesson plan, (2) presenting and implementing writing process which includes: pre-writing activity, whilst writing activity, and post writing activity, and (3) Providing pictures. It can use in the teaching learning process because it was very cheap, easy to get and interesting to the students.

2. The Students

The students' hopes to increase their ability in English especially for writing, and the pictures can be one media to improve their ability in writing descriptive paragraph. The explanation about the using of adjectives and coordination conjunction can help them to connect the ideas in paragraph and make it clearer.

\section{BIBLIOGRAPHY}

Brown, H. Doglas. 1987. Principles of Language Learning and Teaching (Second, ed). Englewood Cliffs, New Jersey: Pretice-Hall, Inc

Corder, S.Pit. 1982. Introducing Applied Linguistics (Reprint). Harmondsworth Middlesex: Penguin Books Limited

Eschholz, Paul, Rosa, Alfred, and Clark, Virginia (Eds) 1978. Language Awareness. New York: St. Martin's Press

Evans, Bergen. 1978. The Power of Words in P. Eschholz, A. Rosa and $V$. Cark (Eds). Language Awareness. New York: St. Martin's Press

Hornby, A.S. 1995. Oxford Advance Learner's Dictionary of Current English (Fifth ed). Oxford University Press

Jacobsen, David, Enggen, Paul amd Kauchak, Donald. 1989. Methods for Teaching; A Skill Apporach (Third ed). Columbus: Meerril Publishing Company

Johson, Keith. 2001. An Introduction to Fereign Language Learning and 
Teaching. Essex: Pearson Edication Limited

Klein, Stephen B. 2002. Learning: Principles and Applications (Fourth ed). New York: McgrawHill

Littlewood, William T. 1989. Foreign and Second Language Learning: Language-acquisition Research and Its Implications for the Classroom (Sixth rint). Cambridge: Cambridge University Press

Marsh, Colin. 1996. Handbook for Beginning Teachers. South Melbourne: Addison Wesley longman Pty Limited

Medgyes, Peter. 2001. When the Teacher is a Non-native Speaker in $M$. Celce Muria (Ed). Teaching English as a Second or Foreign Language (Thirt ed.) Boston: Heinle \& Heinle

Mursell, James L. 1954. Successful Teaching-Ist Psychological Principles (Second ed). New York: McGraw-Hill Book Company, Inc

Paul, David. 2003. Teaching English to Children in Asia. Quarry Bay, Hongkong: Logman Asia ELT

Pei, Mario. 1971. Kisah Daripada Bahasa (Translation ed). Jakarta: Bhratara

Price, Karen. 1988. The Use of Tecnology: Verying the Medium in Language Teaching in Wilga $M$, Rivers $(E d)$. Interactive language Teaching Cambridge: Camridge University Press

Ramirez, Arnolfo G. 1995. Creating Contexts for Second Language
Acquisition: Theory and Methods. New York. Longman Publisher

Richards, Jack C. and Schmidt. 2002. Longman Dictionary of Language Teaching and Applied Linguistics. (Third ed). London: Pearson Edication Limited

Rivers, Wilga M. (ed). 1988. Interactive Language Teaching (Third print). Cambridge; Cambridge University Press

Sturtevant, Edgar H. 1947. An Intoduction to Lingusitic Science. New Haven, CT: Yale University Press

Suriasimantri, JS. 1995. Filsafat Ilmu; Sebuah Pengantar Populer (Cet. IX). Jakarta: Pustaka Sinar Harapan

Willace, MJ. 1993. Training Foreign Language Teachers: a Reflective Apporach (Third print). New York: Cambridge University Press

William, Marion and Burden, Robert L. 1997. Psychology for Language Teachers: a Social Contructivist Apporach. Cambridge: Cambridge University Press 